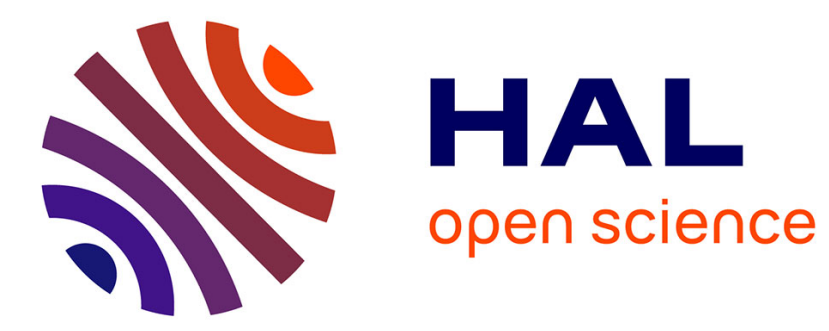

\title{
Understory dynamics after disturbance accelerate succession from spruce to beech-dominated forest-the Siggaboda case study
}

\author{
Andreas Bolte, Lutz Hilbrig, Britt Maria Grundmann, Andreas Roloff
}

\section{To cite this version:}

Andreas Bolte, Lutz Hilbrig, Britt Maria Grundmann, Andreas Roloff. Understory dynamics after disturbance accelerate succession from spruce to beech-dominated forest-the Siggaboda case study. Annals of Forest Science, 2014, 71 (2), pp.139-147. 10.1007/s13595-013-0283-y . hal-01098398

\section{HAL Id: hal-01098398 https://hal.science/hal-01098398}

Submitted on 8 Jan 2015

HAL is a multi-disciplinary open access archive for the deposit and dissemination of scientific research documents, whether they are published or not. The documents may come from teaching and research institutions in France or abroad, or from public or private research centers.
L'archive ouverte pluridisciplinaire HAL, est destinée au dépôt et à la diffusion de documents scientifiques de niveau recherche, publiés ou non, émanant des établissements d'enseignement et de recherche français ou étrangers, des laboratoires publics ou privés. 


\title{
Understory dynamics after disturbance accelerate succession from spruce to beech-dominated forest - the Siggaboda case study
}

\author{
Andreas Bolte • Lutz Hilbrig • Britt Maria Grundmann • \\ Andreas Roloff
}

Received: 2 October 2012 /Accepted: 18 March 2013 /Published online: 19 April 2013

(C) INRA and Springer-Verlag France 2013

\begin{abstract}
- Context It is assumed that climate change will favour European beech (Fagus sylvatica L.) to Norway spruce (Picea abies [L.] Karst.) at its northern range margins due to climate change and induced disturbance events.

- Aims An old-growth mixed forest of spruce and beech, situated near the northern beech margin, was studied to reveal effects of disturbances and response processes on natural forest dynamics, focussing on the understory.

- Methods We carried out analyses on understory dynamics of beech and spruce in relation to overstory release. This
\end{abstract}

Handling Editor: Gilbert Aussenac

Contribution of the co-authors All co-authors have contributed to the writing. Moreover Britt Grundmann and Lutz Hilbrig supported the main author in collecting data and performing analyses. Together with the main author, Andreas Roloff coordinated the study.

A. Bolte $(\bowtie) \cdot$ L. Hilbrig

Johann Heinrich von Thünen-Institute (TI), Institute of Forest

Ecosystems, A.-Möller-Straße 1,

16225 Eberswalde, Germany

e-mail: andreas.bolte@ti.bund.de

L. Hilbrig

e-mail: lutz.hilbrig@ti.bund.de

\author{
A. Bolte \\ Department of Silviculture and Forest Ecology of the Temperate \\ Zones, Georg-August-University Göttingen, Büsgenweg 1, \\ 37077 Göttingen, Germany \\ e-mail: abolte@gwdg.de \\ B. M. Grundmann · A. Roloff \\ Institute of Forest Botany and Forest Zoology, Technical \\ University of Dresden (TUD), Pienner Straße 7, \\ 01737 Tharandt, Germany \\ B. M. Grundmann \\ e-mail: grund@forst.tu-dresden.de \\ A. Roloff \\ e-mail: roloff@forst.tu-dresden.de
}

was done based on a sequence of stand and tree vitality inventories after a series of abiotic and biotic disturbances.

- Results It became apparent that beech (understory) has a larger adaptive capacity to disturbance impacts and overstory release (68\% standing volume loss) than spruce. Understory dynamics can play a key role for forest succession from spruce to beech-dominated forests. Disturbances display an acceleration effect on forest succession in the face of climate change.

- Conclusion Beech is poised strategically to replace spruce as the dominant tree species at the study area. Due to an increasing productivity and a lower risk of stand failure, beech may raise into the focus of forestry in southern Sweden.

Keywords Fagus sylvatica · Picea abies - Climate change · Canopy disturbance $\cdot$ Interspecific competition · Storm · Drought $\cdot$ Bark beetle

\section{Introduction}

Over the past 100 years, mean annual air temperature in Sweden has increased to about $1{ }^{\circ} \mathrm{C}$ (Christensen et al. 2007). For southern Sweden, air temperature projections point to a warming by a further $4{ }^{\circ} \mathrm{C}$ and mean precipitation increase by $11 \%$ until the year 2100 , triggered by anthropogenic climate change (Lind and Kjellström 2008). The warming tendency may result in an extended growing season (Christensen and Christensen 2007). These long-term effects may be overruled by frequent and intensive weather extremes like heat waves and drought episodes as well as intense precipitation events and storms (Nikulin et al. 2011; Donat et al. 2011). For the forests in the region, those increasing abiotic impacts and accompanied biotic threats 
like bark beetle gradations (Schlyter et al. 2006; Jönsson et al. 2007, 2009) form a specific disturbance regime.

The recent natural vegetation in the boreo-nemoral zone (sensu Sjörs 1999) of Southern Scandinavia constitutes of mixed spruce-beech forests. It is there that the northern margin of beech range is overlapping the southern margin of spruce in the lowlands (Björkman 1999).

The long-term warming is reputed to increase the competitive ability of 'nemoral' beech compared to the currently dominant 'boreal' spruce (Grundmann et al. 2011). It is believed that spruce is more susceptible to heat waves and drought due to its shallow root systems (e.g. Schmid 2002) and its adaptation to cold and humid environments, particularly to the northern spruce races (Latałowa and van der Knaap 2006).

Previous analyses in the old-growth spruce-beech forest at Siggaboda reserve (Småland, Southern Sweden) addressed stand dynamics and overstory growth performance (Bolte et al. 2010, Grundmann et al. 2011). This included distinct storm, drought and biotic disturbance impacts on forest structure from 2004 to 2007 and long-term changes in the competing interaction between spruce and beech during the past decades before the disturbances occurred. This study, in contrast, focusses on understory growth dynamics and on its role for post-disturbance forest succession in this natural forest. Moreover, we extended the disturbance analyses with additional interim assessments on the tree health status in 2009 and have performed a new stand growth analysis due to the first reinventory of the stand in 2011. With this information, we want to answer the questions on (1) how (differently) beech and spruce understory are responding to climate change-induced disturbances and overstory release, (2) what role understory dynamics play in natural forest dynamics, and (3) how ongoing disturbance affects the over- and understory interaction, regarding a reputed forest succession from spruce- to beechdominated forest vegetation.

\section{Materials and methods}

\subsection{Site types}

From 2004 to 2011, a long-term study on stand dynamics was conducted at the Siggaboda forest nature reserve in Southern Sweden $\left(56^{\circ} 27^{\prime} \mathrm{N}, 14^{\circ} 33^{\prime} \mathrm{E}\right.$, see also Bolte et al. 2010). The reserve of 70 ha lies near the border between Småland and Blekinge provinces at the southern edge of the boreo-nemoral zone (Sjörs 1999). The climate is humid with a mean annual temperature of $6{ }^{\circ} \mathrm{C}$ and an annual precipitation of around $700 \mathrm{~mm}$ year ${ }^{-1}$. Mean monthly temperature ranges from $-3{ }^{\circ} \mathrm{C}$ in January to $15^{\circ} \mathrm{C}$ in July (Raab and Vedin 1995).

The bedrock is granite gneiss, and massive boulders of up to $5 \mathrm{~m}$ in height are very abundant in the central old-growth area of 5 ha where the mixed spruce-beech stand is located. The fine textured soil material originating from bedrock and admixed moraine sediments is silt- and sand-dominated with low clay content. The relatively poor nutrient content of the parent soil material and the humid climate have induced the development of Haplic Podzols (FAO 2006), overlain by raw humus $(\mathrm{C} / \mathrm{N}$ ratio, 27 to $31 ; \mathrm{pH}(\mathrm{KCl})$, organic layer 3.0 to 3.6, mineral soil 3.4 to 3.9 Bolte et al. 2010).

The main feature of the nature reserve is a central 5 ha old-growth mixed forest of spruce and beech. The beech individuals are up to 250 years old, whereas the spruce individuals reach a maximum age of 140 to 150 years (Grundmann et al. 2011). It is protected since the 1940s, and in 1995, a 65-ha buffer zone was created, featuring coniferous stands of spruce and Scots pine (Pinus sylvestris L.), now between 80 and 115 years old. According to a detailed map of Siggaboda reserve from 1909 by the county authorities (Hannon et al. 2010), the core area seems to have been nearly untouched by logging for at least 100 years, since the then mapped 150-year-old Picea-Fagus stand still exists. However, some extensive use of the forest cannot be excluded (Björkman and Bradshaw 1996).

At the beginning of the study in December 2004, spruce trees were the most abundant tree species followed by beech (Bolte et al. 2010). The stand was then subjected to a succession of intensive disturbance events starting with a hurricane 'Gudrun' in January 2005 featuring wind speeds over $30 \mathrm{~m} \mathrm{~s}^{-1}\left(108 \mathrm{~km} \mathrm{~h}^{-1}\right)$ over large areas of Southern Sweden (Røsting and Kristjánsson 2008) and leading to large windthrown forest areas in the region. The growing season of the subsequent year, 2006, was extraordinary hot, and there was a mid-summer heat and drought period in June and July (precipitation, 28 and $58 \mathrm{~mm}$; temperature, 1. $4{ }^{\circ} \mathrm{C}$ to $4.5^{\circ} \mathrm{C}$ above means; Bolte et al. 2010), which lasted well into the autumn with mean temperatures in October over $10{ }^{\circ} \mathrm{C}$ (WeatherOnline 2011). In 2007, the first indications of a spruce decline due to a bark beetle (Ips typographus) outbreak were visible. This decline process has continued until the last stand recording in April 2011 (Table 1).

\subsection{Field assessments}

For stand assessments, we applied the 'core plot' approach adopted from the forest nature reserve monitoring in Northern Germany (Meyer 2005). Following this, a 1-ha square core plot was placed subjectively in the centre of the reserve's old-growth area in order to select a typical structure of the least disturbed old-growth forest. We divided the plot into 25 subplots of $400 \mathrm{~m}^{2}$ with a grid of $20 \mathrm{~m}$ (Meyer et al. 2001). The 36 edge points of the subplots were permanently marked with wooden stakes, and we determined their positions using an ultrasonic hypsometer 
Table 1 Stand structural traits of the core plot stand (1 ha) including standing and living trees; dbh is the diameter at breast height $(1.3 \mathrm{~m}$ above ground); data includes tree increment and tree ingrowth

Slight variation compared to values reported for 2004 in Bolte et al. (2010) are due to reassessments of tree status (lying/standing, living/dead) in 2004 by 2011 status

\begin{tabular}{llllll}
\hline Species & $\begin{array}{l}\text { Mean dbh } \\
\text { dg }(\mathrm{cm})\end{array}$ & $\begin{array}{l}\text { Mean height } \\
\text { hg }(\mathrm{m})\end{array}$ & $\begin{array}{l}\text { Tree number } \\
\left(\mathrm{n} \cdot \mathrm{ha}^{-1}\right)\end{array}$ & $\begin{array}{l}\text { Basal area } \\
\left(\mathrm{m}^{2} \cdot \mathrm{ha}^{-1}\right)\end{array}$ & $\begin{array}{l}\text { Growing stock } \\
\left(\mathrm{m}^{3} \cdot \mathrm{ha}^{-1}\right)\end{array}$ \\
\hline $\begin{array}{l}\text { December 2004 } \\
\text { Norway spruce }\end{array}$ & 35.9 & 28.0 & 264 & 26.7 & 350.2 \\
European beech & 19.9 & 16.4 & 182 & 5.5 & 45.2 \\
Other species & 20.8 & 16.1 & 40 & 0.8 & 6.7 \\
& & Total & 486 & 33.0 & 402.1 \\
April 2011 & & & & & \\
Norway spruce & 24.0 & 21.9 & 151 & 6.7 & 78.9 \\
European beech & 19.9 & 15.9 & 181 & 5.6 & 46.3 \\
Other species & 14.5 & 16.2 & 31 & 0.5 & 4.4 \\
& & Total & 363 & 12.9 & 129.6 \\
\hline
\end{tabular}

(Vertex III, Haglöf Inc. Sweden) and a compass (PM5/400PC, Suunto Inc., Finland).

Both in December 2004 and April 2011, all trees and snags with a diameter at breast height $(d b h)$ of $7 \mathrm{~cm}$ and larger were recorded on the entire core plot. In 2004, each selected tree specimen was temporarily marked and numbered with a tagging system (Signumat, Latschenbacher, Austria). The recordings included stem position using hypsometer and compass, tree species and diameter at breast height $(d b h)$ using girth tape. In a central subsample of nine subplots ( 0.36 ha area), we additionally recorded tree crown base height $(c b h)$, crown mid height ( $\mathrm{cmh}$, where maximum crown width occurs) and tree top height $(t h)$. Before the start of the growing season in 2005, we made a single recording of the horizontal crown extension from the orthogonal projection of eight outermost crown edge points. The positions of the edge points were determined and marked using a $45^{\circ}$ mirror with sighting aperture and position marking system (Göttingen University, Germany). Subsequently, we leveled it with their cardinal coordinates with the abovementioned equipment. In July 2007 and June 2009, the vitality status of all trees within the core plot was assessed by identifying dead and dying trees and the causes for decreased vitality.

\subsection{Data analysis}

We used the software bundle Statistica 9 (StatSoft 2009) for all statistical analyses.

Analyses on stand structure dynamics from 2004 to 2011, including assessments on crown dimension $(c d)$, basal area $(b a)$ and wood volume ( $w v)$, as well as three-dimensional stand mapping were performed with the stand simulator BWIN-Pro 7 (Nagel et al. 2006). Recorded tree dimension increments $(c d, b a, w v)$ from 2004 to 2011 were linearly interpolated to obtain values for the intermediate vitality assessment dates in 2007 and 2009. In 2011, sapling ingrowth was also recorded.
Non-measured height values of the outer subplots were derived from the measured diameter at breast height $(d b h)$ with a stand height curve based on the Petterson function (Petterson 1955). Missing crown dimension data derived from measured $\mathrm{dbh}$ and derived height data applying an empirical function of Pretzsch et al. (2002).

The competition-growth relationships within the study period from 2004 to 2011 were analysed calculating a competition index $C I$ (Pretzsch et al. 2002) for each tree specimen of the core area defined as reference tree. $C I$ is a distance- and dimension-dependent competition index that considers differences of height and crown extension between reference tree and competitors. We identified the competitors of the reference tree applying the 'virtual reverse cone' method with $60^{\circ}$ vertex angles of the cone and a cone basis height of $60 \%$ of tree height. All surrounding tree specimens with tree tops within the virtual cone were defined as competitors of the reference tree. More detailed information on the procedures is provided by Bolte et al. (2010).

Based on the repeated stand inventory in 2011, we also calculated the growth response of spruce and beech to the disturbance event sequence. We used relative increment parameters like dbh and tree height increment from 2004 to 2011 in relation to the initial dimension in 2004. This was done in order to compare species-specific asymmetry of dimension increment (cf. Yue et al. 2008) along the size spectrum of both species. This allows the comparison of tree cohorts differing in age which are often found for understory beech in the core plot stand.

\section{Results}

\subsection{Disturbance impacts and overstory release}

Total growing stock of the old-growth stand in the core plot increased from $539 \mathrm{~m}^{3} \mathrm{ha}^{-1}$ in 2004 to $565 \mathrm{~m}^{3} \mathrm{ha}^{-1}$ in 2011 (Fig. 1). However, the share between living stand and dead 
Fig. 1 Total stock dynamics from December 2004 to April 2011 including living as well as standing and lying dead stand volume. 'Old' lying dead wood volume found at the study commencement in December 2004 is not included

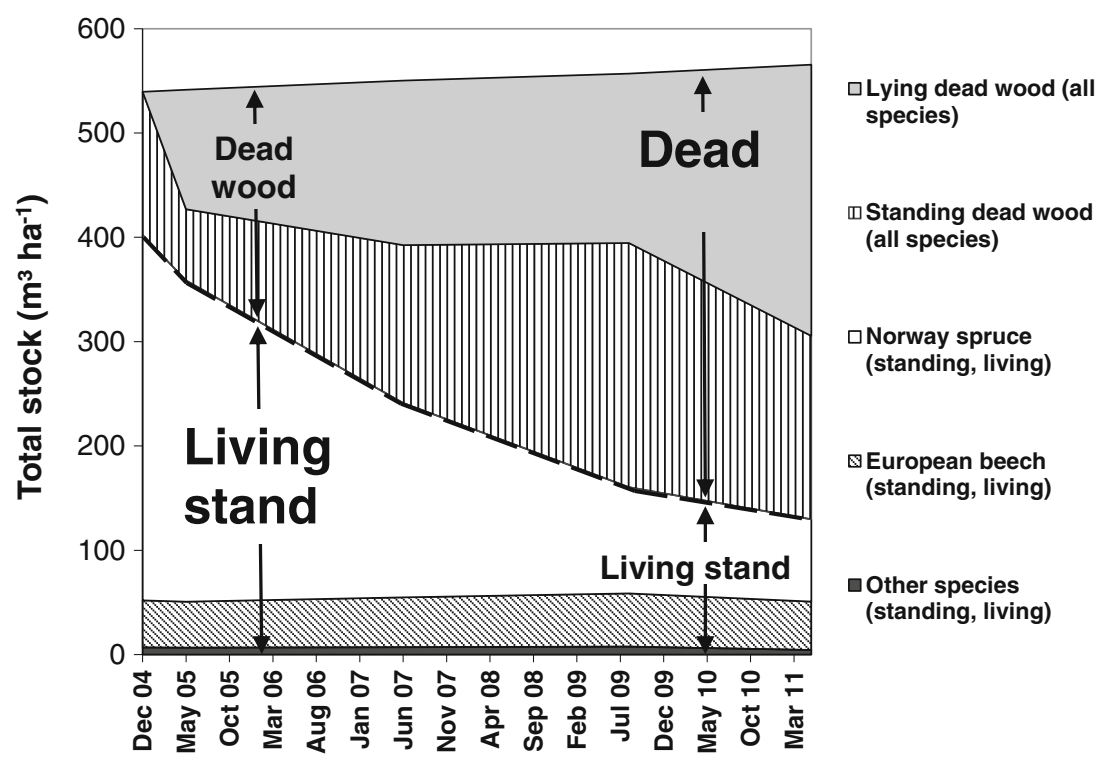

wood components changed drastically due to disturbance events from $25.5 \%$ dead wood proportion in 2004 to 77 . $1 \%$ in 2011. The different disturbance events from 2005 to 2007 (storm, drought and starting bark beetle attacks) and their impacts on living (overstory) stand structure were already presented by (Bolte et al. 2010). The extended time series with the inventories in 2009 and 2011 showed a continued and increased biotic disturbance impact through spruce bark beetle infestations (I. typographus L.). Regarding growing stock dynamics of both living and dead wood stand compartments (Fig. 1), we found in April 2011 only $32 \%$ of the living standing wood volume compared to December $2004\left(402.1 \mathrm{~m}^{3}\right)$, whereas this value was almost $60 \%$ in June 2007 and almost $90 \%$ in May 2005 after the 'Gudrun' storm (Fig. 1, Bolte et al. 2010). These changes were almost completely due to a decline of dominating overstory spruce in the stand losing $79 \%$ of living wood volume; beech and other rare tree species remained nearly unaffected.

Among dead wood volume, a strong variation of standing and lying dead wood compartments is visible (Fig. 1). The increase of lying dead wood material after the storm from 2004 to 2005 was overruled by the raise of standing dead wood volume in the following years with bark beetle damages. However, a huge number of standing dead trees were wind-broken from 2009 onwards, leading to a high lying dead wood volume of $260 \mathrm{~m}^{3}$ in 2011, $93 \%$ of which were Norway spruce. A dense dead wood coverage was found in 2011 in several parts of the core plot where often two or more stems were lying upon each other. European beech was nearly unaffected by the disturbance sequence.

The three-dimensional view onto the core plot stand dynamics (Fig. 2) illustrates the drastic changes in the mixed stand structure and the overstory release. As the result of disturbance event sequence, living spruce was nearly absent in 2011 in the southern part of the core plot where the trees grow on a slightly elevated boulder ridge. Several spruce trees of medium to low dimension were still found in a central depression within the core plot and in the northern part of the plot. Relative to spruce, beech trees were much more abundant and the dominating structural element in 2011.
Fig. 2 Core plot living stand dynamics from 2004 (left figure) to 2011 (right figure). Stand visualization with BWIN-Pro 7 (standing and lying dead trees are not shown), tree dimension changes and tree ingrowth are included. Coneshaped crowns: Norway spruce, elliptical crown shape:

European beech and other broadleaved tree species (very few trees)
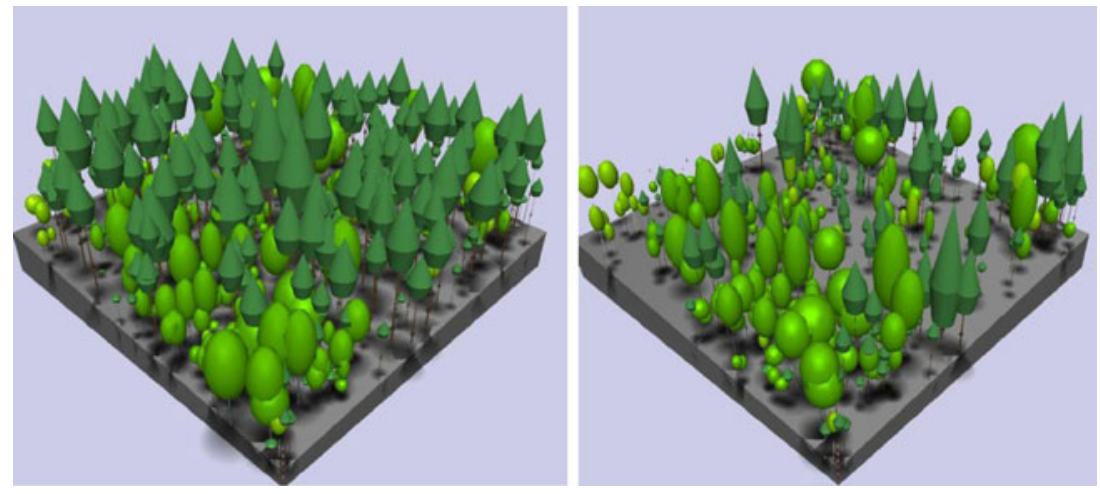


\subsection{Understory response}

Relative dimension increment of trees during and after the disturbance succession increased with decreasing tree size (Fig. 3). This asymmetric growth was found for both species regarding the relative increment of $d b h(i d r)$ and top height (idh) of trees measured both in 2004 and 2011. Thus, understory trees $(d b h<20 \mathrm{~cm}, h \approx 15 \mathrm{~m}$ to $17 \mathrm{~m}$, cf. Peterson curve in Bolte et al. 2010) responded much stronger in growth to the disturbance impacts than the overstory trees. However, more remarkable is that this asymmetry was significantly higher for beech than for spruce (ANCOVA, Table 2) leading to a considerably higher relative diameter and height increment of understory beech compared to that of spruce. The decrease of tree competition during the study period correlates with relative tree volume increment from 2004 to 2011 (Fig. 4). Though the lowering of tree competition index $(C I)$ was strongest for several specimens of the spruce collective, the growth-stimulating effects of competition decrease were considerably higher for beech after reaching a threshold of about 1 $C I$ unit. The increment superiority of beech decreased with increasing $C I$ when compared with spruce. An analysis of covariance (ANCOVA) results in a significant tree species effect on competition-volume increment relations (Table 3). Results of both analyses demonstrate a high growth potential of beech understory during and after the disturbance processes in the old-growth part of the stand. The considerably higher performance of beech understory compared to that of spruce indicates that beech has a competitive advantage compared to spruce in recovery after disturbance.

\section{Discussion}

\subsection{Disturbances and overstory dynamics}

The total effect of disturbance on the overstory at the reserve's core plot during the study period represents a succession of individual impacts due to warming, storm, drought and bark beetle effects; the latter reputed to be increasingly relevant for future dynamics in southern Scandinavia due to climate change (Schlyter et al. 2006; Christensen and Christensen 2007; Jönsson et al. 2007, 2009; Blennow and Olofsson 2008). The remarkable mechanical resistance of the stand to the disastrous storm 'Gudrun' in Januar 2005 (75 million $\mathrm{m}^{3}$ loss of standing wood volume, Komonen et al. 2011) was extensively discussed by Bolte et al. (2010). The following loss of $2 / 3$ of the living standing wood volume until 2011 after the storm and drought events triggered by bark beetle infestations are in line with studies and observations in other spruce dominated forests in Europe. Similar spruce outbreak dynamics were reported after large storm events and droughts like Lothar 1999 and the 2003 drought in Switzerland (Gugerli et al. 2008), several storms in the 1980s and subsequent drought years in the 1990s in the Bavarian Forest (Müller et al. 2008) or the 2003 drought event in the Polish Beskid mountains (Grodzki 2010). Our found bark beetle disturbance dynamics and its triggering process are very similar to those found at Osby nature reserve about only $50 \mathrm{~km}$ southeast of Siggaboda (Komonen et al. 2011), with one exception. In this pure spruce stand, spruce bark beetle killed all spruce specimens in 2006. As beech is reputed to mitigate the risk of bark beetle attacks (Pretzsch and Schütze 2005; Seidl et al. 2008), the prolonged decline of spruce at Siggaboda old-growth area may be due to the mixed forest conditions there.

\subsection{The role of understory dynamics for forest succession}

The found strong growth response of beech understory to overstory release or liberation is remarkable, and at the first glance, this contradicts ideas of this species as a slowgrowing late-successional tree species (Ellenberg 1988). However, at Siggaboda nature reserve, beech is growing not too far from its northern distribution margin in Sweden (Mattarp, northern Småland, Björkman 1996; Kyrkerud, southern Värmland, Fang and Lechowicz 2006). The short growing seasons and low winter temperatures (Bolte et al. 2007) strongly limited growth conditions, which clearly favours spruce to beech at the time the study was initiated
Fig. 3 Relationships between (a) breast height diameter $(d b h)$ and relative diameter increment $(i d r)$ for beech and spruce; (b) tree top height $(t h)$ and relative height increment (ihr); only tree specimen measured twice in 2004 and 2011 with positive increment are included. Tree species effects on the linear relationships are significant according to an analysis of covariance (ANCOVA. see Table 2)
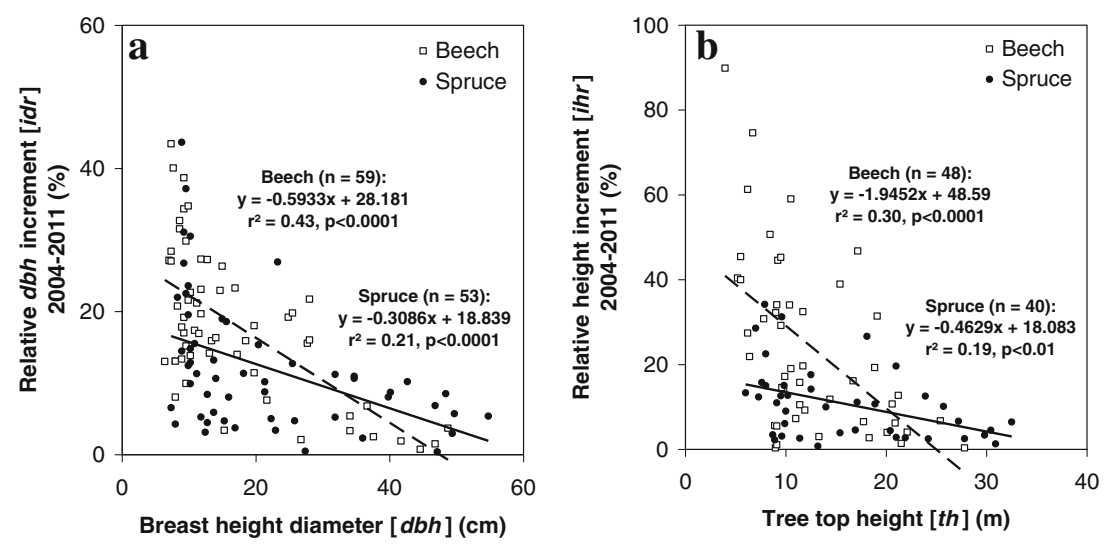
Table 2 Analysis of covariance (ANCOVA), univariate test results of tree species effects on relationships between relative increment ( $i d r$, $i h r)$ and tree dimension ( $d b h$, type III decomposition models with highest coefficients of determination)

\begin{tabular}{llllll}
\hline & SS & DF & MS & $F$ & $P$ \\
\hline$i d r\left(r^{2}=0.33\right)$ & & & & & \\
$d b h$ & $3,209.56$ & 1 & $3,209.56$ & 46.8913 & $<0.01$ \\
Tree species & $20,521.32$ & 2 & $10,260.66$ & 149.9071 & $<0.01$ \\
Error & $7,529.15$ & 110 & 68.45 & & \\
Total & $38,453.11$ & 113 & & & \\
$i h r\left(r^{2}=0.66\right)$ & & & & & \\
$t h$ & $4,432.99$ & 1 & $4,432.99$ & 20.07841 & $<0.01$ \\
Tree species & $23,436.64$ & 2 & $11,718.32$ & 53.07594 & $<0.01$ \\
Error & $18,766.64$ & 85 & 220.78 & & \\
Total & $5,5672.72$ & 88 & & & \\
\hline
\end{tabular}

$d b h$ breast height diameter $(1.3 \mathrm{~m}$ tree height) $(\mathrm{cm}), i d r$ relative $d b h$ increment 2004-2011 (\%), th tree top height (m), ihr relative height increment 2004-2011 (\%); only twice in 2004 and 2011 measured spruce and beech specimens with positive increment were included in the analyses

in 2004 (Bolte et al. 2010). Comparative growth studies on old specimens of both species revealed that beech has already picked up in radial increment relative to spruce over the last decades. This was interpreted as a climate change assisted improvement of beech growth compared with spruce (Grundmann et al. 2011). Beech understory is in particular favoured by the decrease of vertical competition pressure of the spruce dominated canopy, and it is obviously

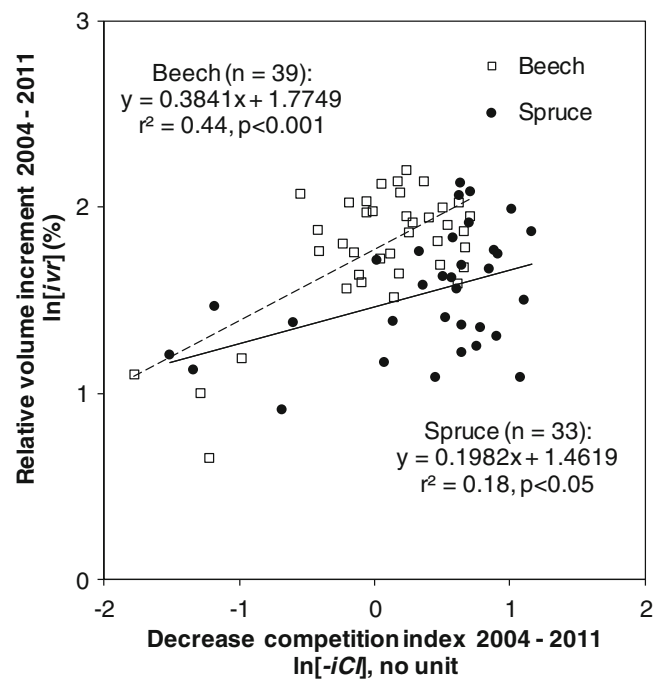

Fig. 4 Relationships between decrease of competition index $(-i C I$. log transformation) from 2004 to 2011 and relative volume increment (ivr. $\log$ transformation) for beech and spruce; only tree specimen measured twice in 2004 and 2011 with positive increment of both diameter (id) and height $(i h)$ are included. Tree species effects on the linear relationships are significant according to an analysis of covariance (ANCOVA, see Table 3)
Table 3 Analysis of covariance (ANCOVA), univariate test results of tree species effects on relationships between relative increment (ivr) and tree competition status (type III decomposition models with highest coefficients of determination)

\begin{tabular}{llllll}
\hline & SS & DF & MS & $F$ & $P$ \\
\hline $\ln [i v r]\left(r^{2}=0.38\right)$ & & & & & \\
$\ln [-i C I]$ & 2.1931 & 1 & 2.19306 & 28.937 & $<0.01$ \\
Tree species & 178.9821 & 2 & 89.49104 & 1180.837 & $<0.01$ \\
Error & 5.2292 & 69 & 0.07579 & & \\
Total & 209.2788 & 72 & & & \\
\hline
\end{tabular}

ivr relative stem volume increment 2004-2011 (\%), -iCI decrease of competition index (CI. no unit) from 2004 to 2011

Only twice in 2004 and 2011 measured spruce and beech specimens with positive volume increment (derived from height and diameter increment) were included in the analyses

more successful than spruce understory in exploiting increased supply of growth resources such as light, water and nutrients. This asymmetric competition favouring beech "from below" is in line with observations and analyses in several strict forest nature reserves in Germany where beech is increasingly dominant in mixed stands previously dominated by other species (Meyer 2005). High morphological plasticity of beech and low light demand (Emborg 1998; Löf et al. 2005, Schröter et al. 2012) are important traits for growing under high interspecific competitive pressure of dominating spruce. Under these conditions, it is very likely that several trees of the beech understory are much older than those of spruce with comparable size, persisting sometimes for several decades with low performance. Ammer et al. (2008) reported on ontogenetic effects on beech seedling development under spruce canopy. Under identical light regimes, older seedlings exhibited a higher height growth than younger ones. Compared to spruce, beech is superior in area acquisition applying a particular ability of lateral and vertical expansion, encircling competitors and filling gaps after disturbances (Pretzsch and Schütze 2005). With this adaptation to disturbance-induced overstory release, beech understory can play a key role for forest succession from spruce to beech-dominated forests at Siggaboda area and probably beyond that. Due to this, single disturbances or disturbance sequences may have an 'accelerating function' for forest dynamics (cf. Fischer et al. 2002) and for forest succession on stand scale in the face of climate change (Mailly et al. 2000).

\subsection{Theory for climate change-induced forest succession}

Previous and current presented analyses of stand structure dynamics are summarized within a conceptual scheme for climate change-induced forest succession in the Siggaboda area (Fig. 5). The 'impact and response pathways' are divided 
Fig. 5 Conceptual scheme for climate change-driven forest succession at Siggaboda core plot area: interacting disturbance and resilience processes of stand dynamics induced by warming, storm, drought, and bark beetle effects (framed). Major processes are indicated with solid arrows; associated processes with dashed arrows

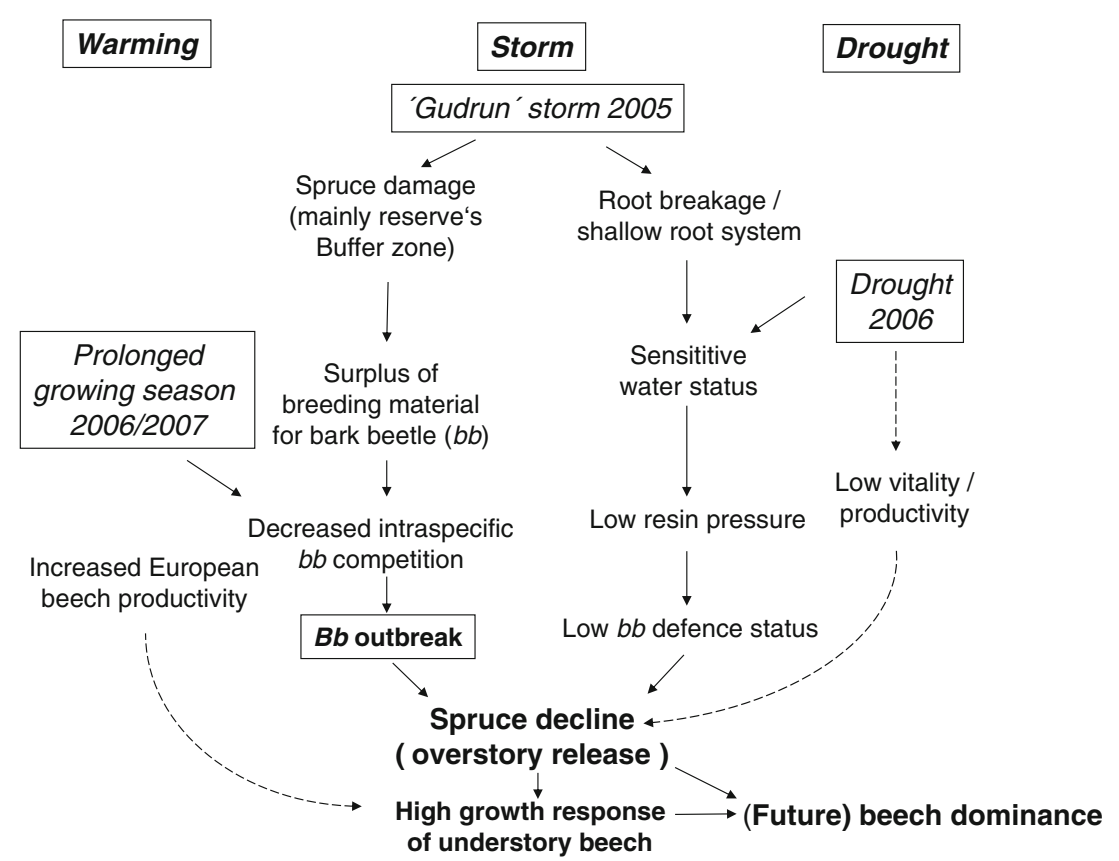

into warming, storm and drought effects of climate change. Direct storm impacts include the accumulation of windthrown and damaged spruce wood volume that represented a surplus of breeding material for bark beetles, in particular $I$. typographus L (Schelhaas et al. 2003; Økland and Berryman 2004). Though only low volumes of wind-damaged spruce trees were found within the 5-ha-old growth area, much higher volumes were found in the surrounding buffer zones with pure coniferous stands where the damaged and dead spruce wood material was left to promote biodiversity of xylobiontic fauna (cf. Komonen et al. 2011). The surplus of breeding material decreased the intensive intraspecific competition among the spruce bark beetles that limits their reproductive success and thus keeps their population on an endemic level (Eriksson 2007). Here, an interaction with warming effects occur: the warm and exceptionally long lasting growing season in 2006 as well as the warm winter 2006/07 and early spring 2007 (Bolte et al. 2010) provided good swarming, reproduction and hibernation conditions that should enable two bark beetle generations to complete their development (Komonen et al. 2011). Moreover, the second generation sustained during winter (cf. Jönsson and Bärring 2010). It is likely that first bark beetle attacks on standing living spruces occurred in 2006, the second summer after the storm (cf. Schroeder 2001) when their defensive system were weak during the summer drought. In particular, the highest and oldest spruce specimens seemed to be among the first trees that were attacked due to a high drought stress disposition and a low defensive system status (Fig. 3, Bolte et al. 2010). This disposition is due to storminduced tree movement of larger spruce trees and lifting of the soil-root plate may have led to hidden but extensive breakage of the finer roots (Coutts 1983, 1986) which have an important function in water and nutrient acquisition (cf. Atkinson 2000). Thus, the 2006 drought resulted in a sensitive collective of spruce trees, which, more than likely have partly damaged and shallow root systems (Puhe 2003) causing a problem for large, tall trees (around $40 \mathrm{~m}$ ) with high transpiration (Herzog et al. 1998) and increasing xylem pressure of crown branches for water transport against gravity (cf. Koch et al. 2004). Beside probable vitality and productivity losses, the low water status of spruce decreases its major defensive ability against bark beetles based mainly on resin exudation (Franceschi et al. 2005).

Despite the probable initial bark beetle attacks on weakened living spruce during the drought summer of 2006, a prolonged mortality period from 2007 to 2011 (cf. Faccoli 2009) occurred that left only a few spruce trees alive. This is due to the increasing bark beetle population growth. With raising breeding material provision, bark beetles can overcome the defence system of less weakened spruce, leading to this spruce overstory decline.

This overstory spruce decline is accompanied with the previously discussed performance and growth stimulation of the beech understory outcompeting spruce understory. This results in beech becoming the dominant tree species in the overstory as well as the understory, climate change-induced disturbances have accelerated this process.

\section{Conclusions}

With its remarkable adaptive capacity to regional climate change including both long-term warming and disturbance events, beech is poised strategically to replace spruce as the 
dominant structural element at Siggaboda old-growth area. In accordance with other consistent analyses about disturbance impacts on spruce in Sweden (Schlyter et al. 2006; Jönsson et al. 2007, 2009; Komonen et al. 2011), the outcome of this study suggests that disturbance impacts as well as overstory release can restrict the spruce's competitive ability to beech in Southern Scandinavia. The risk of a catastrophic loss of high timber volumes in spruce stands will probably increase as well as the efforts to maintain forest structures against an increasing successional pressure (cf. Bolte et al. 2009). Moreover, more frequent storm impacts will lead to a pervasive and significant growth reduction of spruce on a landscape scale that was found for years after the 'Gudrun' storm (Seidl and Blennow 2012). Thus, beech and perhaps also other broadleaved species may rise into the focus of forestry in southern Sweden due to higher productivity and lower risk of stand failure.

Acknowledgments Dr. Tomasz Czajkowski (Thünen Institute of Forest Ecosystems Eberswalde), Heiko Rubbert, Dr. Thomas Kompa, Frauke Koch, Friederike Kampf, René Grippert (Göttingen University) and Dr. Lars Droessler (SLU Alnarp) supported us in field work. We thank all for the outstanding assistance.

Funding This study was funded by the German Research Foundation (Deutsche Forschungsgemeinschaft, DFG: RO 910/10, BO 1906/3), the Thure Rignells Foundation (Tranemåla Erik och Ebba Larssons samt Thure Rignells Stiftelse, Bengt Ljungström) and was conducted in cooperation with the Broadleaf Program (Ädellövprogrammet) of the Swedish Agricultural University (SLU), Southern Swedish Forest Research Centre at Alnarp (Prof. Dr. Magnus Löf, Prof. Dr. Jörg Brunet).

\section{References}

Ammer C, Stimm B, Mosandl R (2008) Ontogenetic variation in the relative influence of light and belowground resources on European beech seedling growth. Tree Physiol 28:721-728. doi:10.1093/treephys/28.5.721

Atkinson D (2000) Root characteristics: why and what to measure. In: Smit AL, Bengough AG, Engels C, Van Noordwijk M, Pellerin S, Van De Geijn SC (eds) Root methods: a hand book. Springer, Berlin Heidelberg New York, pp 2-32

Björkman L (1996) Long-term population dynamics of Fagus sylvatica at the northern limits of its distribution in southern Sweden: a paleoecological study. Holocene 6:225-234. doi:10.1177/095968369600600208

Björkman L (1999) The establishment of Fagus sylvatica at the standscale in southern Sweden. Holocene 9:237-245. doi:10.1191/ 095968399668494320

Björkman L, Bradshaw R (1996) The immigration of Fagus sylvatica L. and Picea abies (L.) Karst. into a natural forest stand in southern Sweden during the last 2000 years. J Biogeogr 23:235-244. doi:10.1046/j.1365-2699.1996.00972.x

Blennow K, Olofsson E (2008) The probability of wind damage in forestry under changed wind climate. Clim Change 87:347-361. doi: $10.1007 / \mathrm{s} 10584-007-9290-\mathrm{Z}$

Bolte A, Czajkowski T, Kompa T (2007) The north-eastern distribution range of European beech-a review. Forestry 80:413-429. doi:10.1093/forestry/cpm028
Bolte A, Ammer C, Löf M, Madsen P, Nabuurs GJ, Schall P, Spathelf P, Rock J (2009) Adaptive forest management in Central Europeclimate change impacts, strategies and integrative concept. Scand J For Res 24:473-482. doi:10.1080/02827580903418224

Bolte A, Hilbrig L, Grundmann B, Kampf F, Brunet J, Roloff A (2010) Climate change impacts on stand structure and competitive interactions in a Southern Swedish spruce-beech forest. Eur J Forest Res 129:261-276. doi:10.1007/s10342-009-0323-1

Christensen JH, Christensen OB (2007) A summary of the PRUDENCE model projections of changes in European climate by the end of this century. Clim Change 81:7-30. doi:10.1007/ s10584-006-9210-7

Christensen JH, Hewitson B, Busuioc A, Chen A, Gao X, Held I, Jones R, Kolli RK, Kwon W-T, Laprise R, Magaña Rueda V, Mearns L, Menéndez CG, Räisänen J, Rinke A, Sarr A, Whetton, P (2007) Regional climate projections. In: Solomon SD, Manning M, Chen Z, Marquis M, Averyt KB, Tignor M, Miller HL (Eds.) Climate change 2007: the physical science basis. Contribution of Working Group I to the 4th assessment report of the Intergovernmental Panel on Climate Change. Cambridge University Press, Cambridge, United Kingdom and New York, NY, USA, pp 848-940

Coutts MP (1983) Root architecture and stability. Plant Soil 71:171188. doi:10.1007/BF02182653

Coutts MP (1986) Components of tree stability in Sitka spruce on peaty gley soil. Forestry 59:173-197. doi:10.1093/forestry/ 59.2 .173

Donat MG, Leckebusch GC, Wild S, Ulbrich U (2011) Future changes in European winter storm losses and extreme wind speeds inferred from GCM and RCM multi-model simulations. Nat Hazards Earth Syst Sci 11:1351-1370. doi:10.5194/nhess-11-1351-2011

Ellenberg H (1988) Vegetation ecology of central Europe. Cambridge University Press, Cambridge, United Kingdom, 731 pp

Emborg J (1998) Understorey light conditions and regeneration with respect to the structural dynamics of a near-natural deciduous forest in Denmark. For Ecol Manage 106:83-95. doi:10.1016/ S0378-1127(97)00299-5

Eriksson M (2007) The bark beetle Ips typographus (L.) on patches of dead or dying host trees: estimating the colonization success and risk of consequential tree deaths. PhD Dissertations in Biology no. 46, University of Joensuu, Finland, 68 pp

Faccoli M (2009) Effect of weather on Ips typographus (Coleoptera Curculionidae) phenology, voltinism, and associated spruce mortality in the southeastern Alps. Environ Entomol 38:307-316. doi: $10.1603 / 022.038 .0202$

FAO [Food and Agriculture Organization] (2006) World reference base for soil resources 2006. World Soil Resources Reports 103, FAO, Rome, Italy, 122 pp

Fang J, Lechowicz MJ (2006) Climatic limits for the present distribution of beech (Fagus L.) species in the world. J Biogeogr 33:1804-1819. doi:10.1111/j1365-2699.2006.01533.x

Fischer A, Lindner M, Abs C, Lasch P (2002) Vegetation dynamics in Central European forest ecosystems (near-natural as well as managed) after storm events. Folia Geobotanica 37:17-32

Franceschi VR, Krokene P, Christiansen E, Krekling T (2005) Anatomical and chemical defenses of conifer bark against bark beetles and other pests. New Phytol 167:353-376. doi:10.1111/ j.1469-8137.2005.01436.x

Grodzki W (2010) The decline of Norway spruce Picea abies (L.) Karst. stands in Beskid Śląski and Żywiecki: theoretical concept and reality. Beskydy 3:19-26

Grundmann BM, Bolte A, Bonn S, Roloff A (2011) Impact of climatic variation on growth of Fagus sylvatica and Picea abies in southern Sweden. Scand J For Res 26:64-71. doi:10.1080/ 02827581.2011 .564392

Gugerli F, Gall R, Meier F, Wermelinger B (2008) Pronounced fluctuations of spruce bark beetle (Scolytinae: Ips typographus) populations do not invoke 
genetic differentiation. For Ecol Manage 256:405-409. doi:10.1016/ j.foreco.2008.04.038

Hannon GE, Niklasson M, Brunet J, Eliason P, Lindbladh M (2010) How long has the 'hotspot' been 'hot'? Past stand-scale structures at Siggaboda nature reserve in southern Sweden. Biodivers Conserv 19:2167-2187. doi:10.1007/s10531-010-0830-0

Herzog KM, Thum R, Kronfuss G, Heldstab HJ, Hasler R (1998) Patterns and mechanisms of transpiration in a large subalpine Norway spruce (Picea abies (L.) Karst.). Ecol Res 13:105-112. doi:10.1046/j.1440-1703.1998.00250.x

Jönsson AM, Harding S, Bärring L, Ravn HP (2007) Impact of climate change on the population dynamics of Ips typographus in southern Sweden. Agr For Met 146:70-81. doi:10.1016/j.agrformet.2007.05.006

Jönsson AM, Appelberg G, Harding S, Bärring L (2009) Spatiotemporal impact of climate change on the activity and voltinism of the spruce bark beetle, Ips typographus. Glob Change Biol 15:486-499. doi:10.1111/j.1365-2486.2008.01742.x

Jönsson AM, Bärring L (2010) Future impact on spruce bark beetle life cycle in relation to uncertainties in regional climate model data ensembles. Tellus A 63:158-173. doi:10.1111/j.1600-0870.2010.00479.x

Koch GW, Sillett SC, Jennings GM, Davis SD (2004) The limits to tree height. Nature 428:851-854. doi:10.1038/nature02417

Komonen A, Schroeder LM, Weslien J (2011) Ips typographus population development after severer storm in a nature reserve in southern Sweden. J Appl Entomol 135:132-141. doi:10.1111/ j.1439-0418.2010.01520.x

Latałowa M, van der Knaap WO (2006) Late Quaternary expansion of Norway spruce Picea abies (L.) Karst. in Europe according to pollen data. Quaternary Sci Rev 25:2780-2805. doi:10.1016/ j.quascirev.2006.06.007

Lind P, Kjellström E (2008) Temperature and precipitation changes in Sweden, a wide range of model-based projections for the $21 \mathrm{st}$ century. Swedish Meteorological and Hydrological Institute. Report RMK no. 113, Norrköpping, Sweden, 50 pp

Löf M, Bolte A, Welander NT (2005) Interacting effects of irradance and water stress on dry weight and biomass partitioning in Fagus sylvatica seedlings. Scand J For Res 20:322-328. doi:10.1080/ 02827580500201593

Mailly D, Kimmins JP, Busing RT (2000) Disturbance and succession in a coniferous forest of northwestern North America: simulations with DRYADES, a spatial gap model. Ecol Model 127:183-205. doi:10.1016/S0304-3800(99)00208-2

Meyer P (2005) Network of Strict Forest Reserves as reference system for close to nature forestry in Lower Saxony, Germany. For Snow Landsc Res 79:33-44

Meyer P, Ackermann J, Balcar P, Boddenberg J, Detsch R, Förster B, Fuchs H, Hoffmann B, Keitel W, Kölbel M, Köthke C, Koss H, Unkrig W, Weber J, Willig J (2001) Untersuchung der Waldstruktur und ihrer Dynamik in Naturwaldreservaten. IHW publisher, Eching, Germany, 107 pp [in German]

Müller J, Bußler H, Großner M, Rettelbach T, Duelli P (2008) The European spruce bark beetle Ips typographus in a national park: from pest to keystone species. Biodivers Conserv 17:2979-3001. doi:10.1007/s10531-008-9409-1

Nagel J, Duda H, Hansen J (2006) Forest simulator BWINPro7. Forst und Holz 61:427-429 [in German]

Nikulin G, Kjellström E, Hansson U, Strandberg G, Ullerstige A (2011) Evaluation and future projections of temperature, precipitation and wind extremes over Europe in an ensemble of regional climate simulations. Tellus 63A:41-55. doi:10.1111/j.16000870.2010.00466.x
Økland B, Berryman A (2004) Resource dynamic plays a key role in regional fluctuations of the spruce bark beetles Ips typographus. Agric Forest Entomol 6:141-146. doi:10.1111/j.14619555.2004.00214.x

Petterson H (1955) Die Massenproduktion des Nadelwaldes. Mitt Forstl Forsch-Anst Schwedens 45:392-580 [in German]

Pretzsch H, Biber P, Durský J (2002) The single tree-based stand simulator SILVA: construction, application and evaluation. For Ecol Manage 162:3-21. doi:10.1016/S0378-1127(02)00047-6

Pretzsch H, Schütze G (2005) Crown allometry and growing space efficiency of Norway spruce (Picea abies (L.) Karst.) and European beech (Fagus sylvatica L.) in pure and mixed stands. Plant Biol 7:628-639. doi:10.1055/s-2005-865965

Puhe J (2003) Growth and development of the root system of Norway spruce (Picea abies) in forest stands - a review. For Ecol Manage 175:253-273. doi:10.1016/S0378-1127(02)00134-2

Raab B, Vedin H (eds) (1995) Climate, lakes and rivers. The National Atlas of Sweden. SNA, Stockholm, Sweden

Røsting B, Kristjánsson JE (2008) A successful resimulation of the $7-$ 8 January 2005 winter storm through initial potential vorticity modification in sensitive regions. Tellus A 60:604-619. doi:10.1111/j.1600-0870.2008.00329.x

Schelhaas MJ, Nabuurs GJ, Schuck A (2003) Natural disturbances in the European forests in the 19th and 20th centuries. Global Change Biol 9:1620-1633. doi:10.1046/j.15298817.2003.00684.x

Schlyter P, Stjernquist I, Bärring L, Jönsson AM, Nilsson C (2006) Assessment of the impacts of climate change and weather extremes on boreal forests in northern Europe, focusing on Norway spruce. Clim Res 31:75-84. doi:10.3354/cr031075

Schmid I (2002) The influence of soil type and interspecific competition on the fine root system of Norway spruce and European beech. Basic Appl Ecol 3:339-355. doi:10.1078/1439-179100116

Schroeder LM (2001) Tree mortality by the bark beetle Ips typographus (L.) in storm-disturbed stands. Integr Test Manage Rev 6:169-175. doi:10.1023/A:1025771318285

Schröter M, Härdtle W, Oheimb GV (2012) Crown plasticity and neighborhood interactions of European beech (Fagus sylvatica L.) in an old-growth forest. Eur J Forest Res 131:787-798. doi:10.1007/s10342-011-0552-y

Seidl R, Rammer W, Jäger D, Lexer MJ (2008) Impact of bark beetle (Ips typographus $\mathrm{L}$.) disturbance on timber production and carbon sequestration in different management strategies under climate change. For Ecol Manage 256:209-220. doi:10.1016/ j.foreco.2008.04.002

Seidl R, Blennow K (2012) Pervasive growth reduction in Norway spruce forests following wind disturbance. PLoS One 7:e33301. doi:10.1371/journal.pone.0033301

Sjörs H (1999) The background: geology, climate and zonation. In: Rydin H, Snoeijs P, Diekmann M (Eds.) Swedish Plant Geography. Acta Phytogeogr Suec 84:5-14

StatSoft Inc (2009) STATISTICA for Windows, version 9.0. Available from http://www.statsoft.com (accessed 28 December 2011)

WeatherOnline (2011) Climate Robot: Växjö/Kronoberg (186 m). Available from http://www.weatheronline.co.uk/Sweden/ VaexjoeKronob.htm (accessed 28 December 2011)

Yue C, Kohnle U, Hein S (2008) Combining tree- and stand-level models: a new approach to growth prediction. For Sci $54: 553-566$ 